\title{
Eröffnung der Tagung am 13. Oktober 1955
}

Der Vorsitzende (Jahrreiß) eröffnete die Tagung. Der Dekan der Rechtswissenschaftlichen Fakultät der Universität Hamburg, Herr Schultze-von Las a ulx, begrüßte die Vereinigung im Namen des Rektors und der Fakultät. Der Vorsitzende gab dem herzlichen Dank der Vereinigung Ausdruck für alle Fürsorglichkeit, die der Senat von Hamburg, die Universität und vor allem die Fakultät der Vorbereitung und Durchführung der Tagung gewidmet haben.

In einem Nachruf auf Ludwig Adamovich, Walter Hen rich und Walter Jell inek würdigte der Vorsitzende den schweren Verlust, den Wissenschaft und Lehre durch das Ableben dieser drei Gelehrten im Jahre 1955 erlitten hat. 